\title{
Price and Condition Parity Clauses in Contracts Between Hotel Booking Platforms and Hotels
}

\author{
Mark-Oliver Mackenrodt
}

Published online: 4 November 2019

(C) The Author(s) 2019

\begin{abstract}
Price parity clauses on digital platforms, such as hotel booking platforms, have been the subject of divergent decisions under Art. 101 TFEU by courts and competition authorities in many EU Member States. These decisions have revealed significant differences between and even within single Member States with regard to the dogmatic treatment of price parity clauses, the factual assessment and the legal outcome. Some countries have even introduced special legislation with regard to price parity clauses. The Swedish Patent and Market Court of Appeals in May 2019 declared narrow price parity clauses to be consistent with Art. 101 TFEU. Only a few weeks later the German Düsseldorf Court of Appeals (Oberlandesgericht, OLG) overturned a decision by the German Competition Authority (Bundeskartellamt) and also held that narrow price parity clauses are valid. This case is on appeal to the German Supreme Court (Bundesgerichtshof). However, the judgments by the two courts of appeals are at odds with regard to their dogmatic approach to Art. 101 TFEU and to the factual findings. Against this background, the Swedish court of appeals' judgment casts light on several aspects that might be of relevance for similar cases in other jurisdictions or that require clarification by a referral to the ECJ or by the lawmakers.
\end{abstract}

Keywords Price parity clauses $\cdot$ Best price clauses $\cdot$ Hotel booking platforms

\footnotetext{
M.-O. Mackenrodt ( $₫)$

Dr. Dr., LL.M. (NYU), Attorney-at-Law (New York); Senior Research Fellow, Max Planck Institute for Innovation and Competition, Munich, Germany

e-mail: mark.oliver@ip.mpg.de
} 


\section{Introduction}

A recent competition law judgment of the Swedish Patent and Market Court of Appeals ${ }^{1}$ deals with price and condition parity clauses ${ }^{2}$ in contracts between hotel booking platforms and hotels. It raises important issues regarding Art. 101 TFEU.

\subsection{Importance of the Case}

The judgment is of high interest for several reasons. Price parity clauses of hotel booking platforms have been the subject of competition law proceedings in several Member States but not yet at the European Union level. Even though the different national competition authorities and courts have applied the same provision, namely Art. 101 TFEU, their factual and legal assessment of price parity clauses has reached different results. Even within single national jurisdictions a divergent dogmatic treatment of best price clauses within Art. 101 TFEU can be observed. In addition, some Member States have even implemented legislation in order to outlaw certain kinds of best price clauses. The topic is of general legal and economic interest as best price clauses can also be found in sectors other than the hotel booking market and their competitive assessment is of high economic importance for the development of the digital platform economy.

\subsection{The Business Model of Hotel Booking Platforms}

Price parity clauses can be found in the general terms and conditions between hotel booking platforms and hotels. A hotel booking platform constitutes a two-sided market that brings together customers who want to book a hotel room and hotels that offer accommodations. When using the platform, hotel room customers do not have to pay a direct fee to the platform. By contrast, the hotels have to pay a percentage fee of around $10-15 \%$ of the price of the hotel room to the platform if a hotel room customer books one of their rooms by using the platform.

Instead of using the booking platform, a hotel room customer might book the room directly with the hotel, either on the hotel website or offline. In this case the hotel saves the percentage fee and might therefore offer the room at a lower price.

Booking platforms are concerned that customers could search for a room on the platform website and then book the room at a lower price directly with the hotel or through a different distribution channel. The platform could avoid such free-riding through different measures, for example by replacing the percentage fee by a payper-click fee or by a fixed fee for registered hotels or customers. However, platforms seek to avoid free-riding by including price parity clauses in their contracts with hotels and by promising hotel room customers that they will not find their particular hotel room at a lower price elsewhere.

\footnotetext{
1 Svea Hovrätt, 9 May 2019, PMT 7779-18 - booking. For a translation of this decision, see this issue of IIC at https://doi.org/10.1007/s40319-019-00884-z. The judgment is not open to an appeal.

2 Such clauses are also referred to as "best price clauses".
} 


\subsection{Different Forms of Price Parity Clauses}

To understand the various court decisions on price parity clauses on hotel booking platforms, it is important to distinguish between the different forms of price parity clauses. So-called "wide" price parity clauses in essence prohibit hotels from offering their rooms at a lower price through any other distribution channel. ${ }^{3}$ "Narrow" price parity clauses may instead preclude a hotel from offering its rooms at a lower price in all distribution channels except for competing booking platforms and its offline marketing. ${ }^{4}$ These clauses include a prohibition of lower prices on the hotel's own website. Nevertheless, price parity clauses can - depending on their contractual drafting - take a wide range of different forms. Platforms might monitor and enforce compliance with their price parity clauses and sometimes even impose penalties for non-compliance. The narrow price parity clauses that were assessed by the Swedish court of appeals prevented hotels from advertising their rooms at a lower price on their own hotel websites.

\section{The Legal Framework for Assessing Price Parity Clauses}

The legal framework for assessing price parity clauses under Art. 101 TFEU can be briefly outlined as follows: The court or authority would first assess whether a price parity clause constitutes a restraint of competition in the sense of Art. 101(1) TFEU. It has also been discussed whether an unwritten exception to Art. 101(1) TFEU applies because narrow price parity could constitute an ancillary restraint ${ }^{5}$ that is necessary for a business model to function. A justification for an anti-competitive agreement in the sense of Art. 101(1) TFEU can be based on the vertical block exemption regulation 330/2010. ${ }^{6}$ However, this regulation is inapplicable at the outset if the market share of the booking platform exceeds the threshold of $30 \%$. In this case the anti-competitive contractual clause could still be justified if it meets the four requirements laid down in Art. 101(3) TFEU. In short, Art. 101(3) TFEU requires that the contractual clause in question improves the distribution of goods and allows consumers a fair share of the resulting benefits. Further, the restrictions need to be indispensable for attaining these objectives and must not eliminate competition in respect of a substantial part of the market.

\footnotetext{
3 E.g. the hotel's own website, competing booking platforms and other online or offline channels.

4 A similar "narrow price parity clause" was the subject of the most recent German judgment of OLG Düsseldorf, 4 June 2019, VI-Kart 2/16 (V) - booking.

5 A general introduction to the concept of ancillary restraints is provided by Faull and Nikpay, "The EU Law of Competition" (2014), paras. 3.235-3.292. Best price clauses are not addressed.

${ }^{6}$ Regulation (EU) 330/2010 of the European Commission of 20 April 2010 on the application of Article 101(3) of the Treaty on the Functioning of the European Union to categories of vertical agreements and concerted practices, OJ L 102/1-7, 23 April 2010.
} 


\section{Divergent Legal Approaches to Price Parity Clauses in Germany}

As a background for assessing the decision of the Swedish court of appeals and in order to demonstrate the divergence of approaches between jurisdictions and even within a single Member State, the competition law treatment of price parity clauses in Germany can be summarized as follows:

Wide price parity clauses of the hotel booking platform HRS, which held a market share of over 30\%, were found to be in violation of Art. 101 TFEU by the German antitrust authority (Bundeskartellamt) in 2013. ${ }^{7}$ This decision was upheld by the Düsseldorf Court of Appeals and is final. ${ }^{8}$ It was held that wide parity clauses restrain competition in the sense of Art. 101(1) TFEU and are not justified by Art. 101(3) TFEU. Several contentious issues with regard to the application of the vertical block exemption regulation $330 / 2010$ to parity clauses were identified ${ }^{9}$ but could be left open, since in the case at hand regulation 330/2010 did not apply due to HRS' large market share.

Wide price parity clauses of the hotel booking platform expedia, which had a market share below 30\%, were considered to be valid in a private enforcement action. The Cologne District Court (Landgericht) in the first instance ${ }^{10}$ and the OLG Düsseldorf ${ }^{11}$ in the second (and final) instance ruled that wide price parity clauses constitute a violation of Art. 101(1) TFEU but in the case at hand were justified by the vertical block exemption regulation.

In 2015 the Bundeskartellamt also investigated narrow price parity clauses of the hotel booking platform booking.com and declared them to be illegal. ${ }^{12}$ In an interim decision the OLG Düsseldorf as court of appeals (initially) broadly followed the line of the Bundeskartellamt. ${ }^{13}$ The Bundeskartellamt had argued that narrow best price clauses were an infringement of Art. 101(1) TFEU and were not justified by Art. 101(3) TFEU. The vertical block exemption regulation 330/2010 was not applicable due to booking.com's market share of over 30\%. However, in June 2019 the OLG Düsseldorf ${ }^{14}$ in its main proceedings overturned the decision of the Bundeskartellamt against booking.com and held that narrow parity clauses were valid under Art. 101 TFEU. This ruling is open to an appeal by the Bundeskartellamt before the German Supreme Court (Bundesgerichtshof, BGH).

However, the dogmatic approach taken by the OLG Düsseldorf came at least partly as a surprise. It diverged from the approach taken by the same court in its interim decision and also from the approach taken in other Member States, such as by the Swedish court of appeals in May 2019. The OLG Düsseldorf applied the

\footnotetext{
7 BKartA, 20 December 2013, B9-66/10 - HRS.

${ }^{8}$ OLG Düsseldorf, 9 January 2015, VI-Kart 1/14 (V) - HRS.

9 OLG Düsseldorf, 9 January 2015, VI-Kart 1/14 (V), para. 164 et seq. - HRS; BKartA, 20 December 2013, B9-66/10, para. 181 et seq. - HRS.

${ }^{10}$ LG Cologne, 16 February 2017, 88 O (Kart) 17/16 - expedia.

11 OLG Düsseldorf, 4 December 2017, VI-U (Kart) 5/17 - expedia.

12 BKartA, 22 December 2015, B9-121/13 - booking.

13 OLG Düsseldorf, 4 May 2016, VI-Kart 1/16 (V) - booking.

14 OLG Düsseldorf, 4 June 2019, VI-Kart 2/16 (V) - booking.
} 
ancillary restraints doctrine to narrow best price clauses. Accordingly, the court reasoned that narrow parity clauses constitute a restraint of competition but that due to an unwritten exemption to Art. 101(1) TFEU the prohibition of anti-competitive agreements would not apply. By this reasoning, the German court avoided discussing Art. 101(3) TFEU or the vertical block exemption regulation.

\section{The Swedish Court of Appeals Judgment and Its Appraisal}

In the Swedish court of appeals' case, the narrow price parity clause, just like in the German case against booking.com, barred hotels from advertising and setting prices on their own hotel websites that were lower than those advertised on booking.com's platform. The original claim was brought by Visita, an organization that represents the Swedish tourism industry.

In short, the Swedish Patent and Market Court of Appeals held that the clauses were valid and that the plaintiff had not presented sufficient evidence to prove harm to competition in the sense of Art. 101(1) TFEU. Accordingly, neither the ancillary restraints doctrine nor Art. 101(3) TFEU was discussed. The ruling was accompanied by a dissenting opinion of one judge. The judgment is not open to an appeal.

\subsection{The Swedish First Instance Judgment and Earlier Proceedings}

The Swedish court of appeals has overturned the decision of the preceding instance, where the Swedish Patent and Market Court ${ }^{15}$ held on 20 July 2018 that narrow price parity clauses constituted an infringement of Art. 101 TFEU.

The first instance court discussed and rejected the ancillary restraints doctrine and found a restraint of competition on the platform market for hotel booking services and on the market for hotel rooms: the narrow price parity clauses would prevent hotels from offering lower prices on their own website and create an incentive for hotels not to offer lower prices on rival hotel booking platforms. Justification under Art. 101(3) TFEU was rejected.

In a separate case in 2015 the Swedish Competition Authority had - in a coordinated proceeding with competition authorities from other Member States like France and Italy - found that only wide price parity clauses were in contravention of Art. 101 TFEU and considered narrow price parity clauses to be in conformity with Art. 101 TFEU. These proceedings resulted in commitment decisions. ${ }^{16}$

\subsection{Relevant Markets}

The Swedish court of appeals - largely ${ }^{17}$ in accordance with the district court and with the Swedish competition authority in a separate case - delineated two relevant

\footnotetext{
15 Stockholms Tingsrätt, 20 July 2018, PMT 13013-16 - booking.

16 Konkurrensverket, 15 April 2016, Ref. No. 596/2013 - booking (commitment decision).

17 The Swedish court of appeals - unlike the district court - includes meta search machines that offer booking services in the relevant market.
} 
markets where narrow price parity clauses might cause a restraint of competition: ${ }^{18}$ firstly, the market for the provision of online travel agency services with regard to hotels in Sweden which includes, for example, rival booking platforms and, secondly, the market for hotel rooms in Sweden. The court of appeals assumed that booking.com holds a market share of over 50\%, that expedia holds the second highest market share of around $25 \%$ and that the remaining share of the market is fragmented. ${ }^{19}$

\subsection{Legal and Evidentiary Standards for Assessing Competitive Harm}

At the outset of the competitive analysis, the Swedish court of appeals convincingly found that price parity clauses are not to be assessed within the legal category of a restriction by object. ${ }^{20}$ This category applies to agreements that in their particular legal and economic context are by nature harmful to competition so that a closer analysis of anti-competitive effects was not needed. ${ }^{21}$ A restriction by object does not require that there is an intent to restrict competition or that the sole purpose of the clause consists in restricting competition. However, this category must be interpreted narrowly. The court pointed to the possible benefits of booking platforms as distribution channels that offer transparency and additional services to consumers. $^{22}$ Further, the complexity of two-sided markets and the diverging approaches of competition authorities from different countries to price parity clauses showed that a closer analysis of the competitive effects was warranted.

The Swedish court of appeals then examined whether price parity clauses have the effect of restraining competition. Such an assessment under Art. 101(1) TFEU not only refers to actual effects that have already appeared but also to potential effects on competition that are likely to occur in the future. ${ }^{23}$ The court pointed to the absence of a generally accepted economic theory that would allow qualifying narrow price parity clauses as anti-competitive by their nature. Therefore, the court ruled that it would not be sufficient for the plaintiff to present theories of possible economic harm as a result of best price clauses. ${ }^{24}$ Rather, the court required factual evidence of anti-competitive effects, and noted that narrow price parity clauses had already been in use over a significant time span. For such a showing the plaintiff Visita carried the burden of proof. The court assessed several economic expert

\footnotetext{
18 Svea Hovrätt, 9 May 2019, PMT 7779-18, p. 7 et seq. - booking.

19 Svea Hovrätt, 9 May 2019, PMT 7779-18, p. 13 et seq. - booking.

20 Svea Hovrätt, 9 May 2019, PMT 7779-18, p. 9 et seq. - booking.

21 See, for example, ECJ, C-345/14, Maxima Latvija, 26 November 2015, ECLI:EU:C:2015:784, para. 18.

22 Svea Hovrätt, 9 May 2019, PMT 7779-18, p. 12 et seq. - booking.

23 See, for example, ECJ, C-345/14, Maxima Latvija, 26 November 2015, ECLI:EU:C:2015:784, para. 30; ECJ, C-7/95 P, John Deere, 28 May 1998, ECLI:EU:C:1998:256, para. 77.

24 Svea Hovrätt, 9 May 2019, PMT 7779-18, pp. 17, 18 - booking.
} 
opinions and concluded that they were not sufficiently robust to prove competitive harm.

\subsection{Market for Booking Platforms}

In one line of argument the plaintiff had argued that narrow price parity clauses reduced competition in the hotel online booking platform market. ${ }^{25}$ In particular, competition for lower platform fees would be stifled and new entries into the platform market would be deterred. If a competing platform lowered its commission in order to offer a hotel room for a lower price, the hotel would also prefer to lower the price on its own website. Then, however - due to the best price clauses - prices on the booking.com platform would also have to be lowered even though the fee on this platform would remain unchanged. Therefore, the plaintiff argued that the narrow price parity clause would be the reason why hotels did not differentiate prices between competing distribution channels for their hotel rooms.

However, the Swedish court of appeals found that the economic evidence presented was not sufficient to exclude other reasons than the narrow price parity clauses to explain why hotels refrained from price differentiation between the different distribution channels. One economic study had shown that hotels that were not bound by price parity clauses did not to a higher degree engage in price differentiation between online platforms. ${ }^{26}$ The court noted that such a lack of price differentiation could also be observed for hotels in France and Germany where narrow price parity clauses were prohibited by law or by decisions of the competition authority. ${ }^{27}$

The plaintiff had also argued that the fees of online platforms were 15-18\% while traditional travel agencies would only charge around $10 \%$. The court of appeals, however, held that this was not necessarily an indication of supracompetitive prices and entry barriers with regard to the online booking market because, for example, no evidence had been provided concerning the cost structures in the two fields. ${ }^{28}$

Quite similarly, the court of appeals held that the oligopolistic character and the high entry barriers to the online platform markets were not necessarily due to the narrow price parity clauses but a common feature of platform markets. ${ }^{29}$

In sum, the court of appeals did not consider the economic evidence on which the plaintiff Visita had relied as sufficiently representative and robust to prove that the narrow price parity clauses were the cause of negative competitive effects on the market for online hotel booking platforms in Sweden.

\footnotetext{
25 Svea Hovrätt, 9 May 2019, PMT 7779-18, p. 18 et seq. - booking.

26 Svea Hovrätt, 9 May 2019, PMT 7779-18, p. 18 et seq. - booking.

27 Svea Hovrätt, 9 May 2019, PMT 7779-18, p. 19 et seq. - booking.

28 Svea Hovrätt, 9 May 2019, PMT 7779-18, p. 21 et seq. - booking.

29 Svea Hovrätt, 9 May 2019, PMT 7779-18, p. 22 - booking.
} 


\subsection{Market for Hotel Rooms}

In a second theory of harm, the plaintiff referred to the market for hotel rooms, arguing that prices for hotel rooms would be lower without narrow price parity clauses. If the hotels saved fees for the use of the platform by offering rooms at lower prices on their own websites, they could pass on this cost advantage to consumers. $^{30}$

Again, the Swedish court of appeals rejected the robustness of the economic evidence presented by the plaintiff, holding that the plaintiff had not offered sufficient factual evidence to show that, absent the narrow price parity clauses, hotels would be ready to advertise lower prices on their own hotel websites than on the platform.

By contrast, the dissenting opinion ${ }^{31}$ considered it as probable that - as indicated in one economic expert opinion - without the narrow price parity clauses hotels would have an incentive to lower prices on their own websites. Further, the dissenting opinion ${ }^{32}$ argued that lower prices on the hotel websites would lead to lower fees on the platform. This would result in lower marginal costs for the hotels and, in turn, in lower prices for the rooms.

The court of appeals further held that the plaintiff had not presented sufficient evidence that prices overall would be lower absent the narrow price parity clause. It found that, absent the price parity clause, the hotels might just as well choose to present lower prices on their own websites by increasing prices on the booking platform. ${ }^{33}$ In contrast, the dissenting opinion ${ }^{34}$ pointed to the significance of the platform as a booking channel. An increase in price on the platform would, therefore, lead to quantity losses for the hotel. This effect would, indeed, counteract the incentive to increase prices on the platform.

\section{Possibly Relevant Aspects for Cases in Other Jurisdictions}

The Swedish court of appeal's judgment casts light on several aspects which might be of relevance for similar cases in other jurisdictions or require clarification by a referral to the ECJ or by the lawmakers.

\subsection{The Court's Indirect Admission that Parity Clauses Are Not Necessary}

The Swedish court of appeals' decision hinges largely on the holding that the empirical economic expert opinions were not sufficiently robust in showing that, absent the narrow price parity clauses, hotels would potentially advertise lower

\footnotetext{
30 Svea Hovrätt, 9 May 2019, PMT 7779-18, p. 22 - booking.

31 Svea Hovrätt, 9 May 2019, PMT 7779-18, p. 27 - booking.

32 Svea Hovrätt, 9 May 2019, PMT 7779-18, p. 27 - booking.

33 Svea Hovrätt, 9 May 2019, PMT 7779-18, p. 24 - booking.

34 Svea Hovrätt, 9 May 2019, PMT 7779-18, p. 27 - booking.
} 
prices on their own websites or on rival booking platforms as compared to the prices on the booking.com platform which include the percentage fee.

However, this factual assumption seems to be burdened with a logical inconsistency: if hotels would not choose to advertise lower prices on their own websites anyway, the question arises why then narrow price parity clauses are used and enforced by the hotel platforms. Also, punitive measures by platforms against hotels would be difficult to explain, for example the dimming of platform profiles of hotels that had offered lower prices in different distribution channels. ${ }^{35}$

In addition, the assumption of the Swedish court also contradicts the line of argument of the booking platforms in other cases and of the German court, the OLG Düsseldorf: booking platforms have argued that price parity clauses were necessary for their business model to exist. This argument was used in order to invoke a justification for the clauses under Art. 101(3) TFEU or in order to rely on an exemption to Art. 101(1) TFEU under the ancillary restraints doctrine. In the German case - which is still on appeal - the OLG Düsseldorf followed exactly this reasoning and applied the ancillary restraints doctrine. ${ }^{36}$ It argued at length that the narrow price parity clauses are necessary for the business model to function and that without the clause hotels would have a reason and incentive for a price differentiation. ${ }^{37}$ This argument seems to be at odds with the Swedish court's finding that hotels would, anyway, not engage in price differentiation between different distribution channels. The court's finding implies that best price clauses are not necessary.

In future parity clause cases, the factual finding of the Swedish court might render the reliance on Art. 101(3) TFEU and on the ancillary restraints doctrine more difficult. This would be particularly troublesome as the platform would bear the burden of proof for these defences and would have to show that, without the narrow price parity clauses, hotels would engage in price differentiation. Exactly this assumption of price differentiation by hotels was, however, a prerequisite for the OLG Düsseldorf's holding that the clauses are necessary for the functionality of the platform business model and that, therefore, the price parity clauses fall under the ancillary restraints doctrine.

\subsection{The Court's Narrow Approach to Potential Competitive Effects}

In addition, the Swedish court of appeals seemed to take quite a narrow approach to Art. 101(1) TFEU. Apparently, the court more or less required an empirical showing of actual anti-competitive effects and of actual price differentiation. At the same time, it placed little focus on the concept of potential anti-competitive effects.

\footnotetext{
35 A dimming strategy is addressed in the case OLG Düsseldorf, 4 December 2017, VI-U (Kart) 5/17, para. 16 - expedia. Similar practices seem to have been referred to by the Swedish judgment in the first instance.

36 In the first instance, the Swedish Patent and Market Court had also discussed (and rejected) the ancillary restraints doctrine and a justification under Art. 101(3) TFEU.

37 OLG Düsseldorf, 4 June 2019, VI-Kart 2/16 (V), p. 16 et seq. - booking.
} 
The court correctly spelled out that the concept of restraints to competition by effect requires a showing of either actual or at least likely or potential harm to competition. The court then stated that, within this concept, a presentation of economic theories in support of the plaintiff's argument would not be sufficient and that factual proof of certain actual circumstances would be required. To support this prerequisite, the court argued that there would be no generally accepted economic theory that narrow price parity clauses are as a rule and by their nature harmful to competition. $^{38}$ This argument, however, seems to be a mere reiteration of the reasons why the court did not apply the restraints by object category under Art. 101(1) TFEU.

Of course, the two categories of restraints by object and restraints by effect are distinguished by the depth of the required competitive analysis. However, the question arises whether within the category "restraints by effect" the court leaves an adequate role for the subcategory of likely and potential effects as opposed to the subcategory of actual effects. The Swedish court of appeals seemed to side-line the subcategory of potential effects using the same argument that it used not to apply the restraints by effect alternative.

Instead of requiring factual proof of an actual price differentiation, the court should have discussed whether the hotels have the possibility and an incentive to advertise lower prices on their own websites without the best price clause. It is, therefore, not surprising that the dissenting judge opined that at minimum there would be a restraint of potential competition in this case. ${ }^{39}$

As an issue of general interest, in a similar case a referral to the European Court of Justice might be warranted. This might help to clarify the practical relevance of the alternative of "effects on potential competition" between the alternatives of "effects on actual competition" and "restraints by object".

\subsection{The Assessment of Empirical Evidence}

The Swedish court of appeals held with regard to both theories of harm that the economic evidence presented by the plaintiff was insufficient to show that, absent the narrow price parity clauses, hotels would advertise lower prices on their own websites. In both circumstances ${ }^{40}$ the court noted that the plaintiffs could have - but actually had not - presented studies that compared the market developments in Sweden with other EU countries like France, where narrow price parity clauses were outlawed by legislation, or like Germany, where narrow price parity clauses were interdicted by the Bundeskartellamt ${ }^{41}$ in 2015.

In Germany, however, the OLG Düsseldorf ${ }^{42}$ only a few weeks later ruled to the contrary and found that narrow price parity clauses were indeed necessary for the business model of booking platforms because otherwise hotels would have the

\footnotetext{
38 Svea Hovrätt, 9 May 2019, PMT 7779-18, p. 18 - booking.

39 Svea Hovrätt, 9 May 2019, PMT 7779-18, p. 28 - booking.

40 Svea Hovrätt, 9 May 2019, PMT 7779-18, pp. 22, 27 - booking.

41 BKartA, 22 December 2015, B9-121/13 - booking.

42 OLG Düsseldorf, 4 June 2019, VI-Kart 2/16 (V) - booking.
} 
possibility and the incentive to advertise lower prices on their own websites. This raises the more general question as to the role of empirical evidence in competition law cases. However, for the German market it must also be considered that the Bundeskartellamt's interdiction of narrow price parity clauses was not final. A pending appeal could be a reason to postpone a change in pricing strategy. More generally, there can be cumulative reasons why hotels do not engage in price differentiation.

As a special feature of the Swedish case, the two major hotel chains, Nordic Choices and Scandic, which have a market share of $25 \%$, are not bound by price parity clauses. The court argued that hotels that were not bound by price parity clauses did not engage in a higher degree of price differentiation. It is not quite clear whether this argument only refers to the two major hotel chains. It would, however, be difficult to infer from the pricing decisions of perhaps only two quite powerful decision-makers that the high number of very dissimilar and much smaller hotels would follow their line and potentially not engage in a different pricing strategy.

\subsection{The Missing Link Between Intra-brand and Inter-brand Competition}

The Swedish court of appeals' argument also borrowed from the field of vertical agreements by distinguishing between intra-brand and inter-brand competition. ${ }^{43}$ Inter-brand competition concerns competition between hotel rooms of different hotel brands. Intra-brand competition refers to competition between different distribution channels which sell hotel rooms of the same hotel and which compete on the quality and price of the distribution. The court found that in the field of vertical distribution there is less concern about restriction of intra-brand competition if there is strong inter-brand competition.

However, in the context of the present case on narrow best price clauses, this argument seems incomplete. Vertical distribution law under certain circumstances accounts for benefits like the protection of investments or improvement of services which are achieved in the context of a restraint of intra-brand competition, but which at the same time strengthen inter-brand competition to the benefit of consumers. Nevertheless, such benefits are not accounted for as such but within a particular balancing process. In the present case, however, a balancing is exactly what the Swedish court of appeals has not done. Unlike the first instance, the court did not discuss Art. 101(3) TFEU or the concept of ancillary restraints. This would, for example, have involved a balancing of effects and would have addressed questions such as whether the restraint is necessary to achieve the alleged efficiencies and whether efficiencies are passed on to consumers.

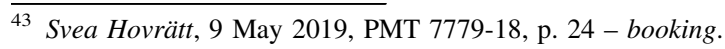




\subsection{Dogmatic Divergences and the Unitary Application of European Competition Law}

The judgment of the Swedish court of appeals points to a lack of a unitary application of European competition law and to dogmatic divergences in the treatment of best price clauses within and between Member States.

The dissenting opinion ${ }^{44}$ in the case followed the first instance judgment and held that narrow price parity clauses do not constitute ancillary restraints which would be outside the scope of Art. 101(1) TFEU. Rather, possible benefits and particularly the free-rider argument should solely be addressed within the framework of Art. 101(3) TFEU. However, as to the dissent, a justification should be rejected because the defendant did not sufficiently show that the restrictions were necessary to achieve the alleged efficiencies. In contrast, the OLG Düsseldorf did apply the ancillary restraints doctrine.

A referral to the European Court of Justice could deliver more clarity as to the ancillary restraints doctrine and the application of Art. 101(3) TFEU in such cases.

Parity clauses are of potential importance for many sectors of the economy. They can take a wide range of shapes and require a complex assessment. It might, therefore, be preferable to address these issues not within the ancillary restraints doctrine, which is an unwritten exemption to Art. 101(1) TFEU, but within the framework of Art. 101(3) TFEU, which provides an established framework for balancing the competitive effects of a clause.

\subsection{Legislation with Regard to Price Parity Clauses}

Several Member States have enacted legislation that directly addresses best price clauses. At the European Union level, parity clauses are being addressed in the recent platform to business (P2B) regulation 2019/1150 on promoting fairness and transparency for business users of online intermediation services. The regulation has entered into force and will apply from 12 July $2020 .{ }^{45}$ It contains rules on contract law, unfair competition law and procedural rules, and seeks to guarantee transparency, fairness and effective redress possibilities on platform markets. ${ }^{46}$ With regard to price parity clauses, Art. 10(1) P2B regulation stipulates that an intermediation platform that uses price parity clauses in its terms and conditions also has to include the main economic, commercial or legal considerations for these restrictions. These grounds need to be easily available to the public.

However, these transparency measures do not effectively address the particular competition law concerns prompted by price parity clauses. Still, Art. 10(2) P2B regulation provides that this provision is not exhaustive and that other limitations

\footnotetext{
44 Svea Hovrätt, 9 May 2019, PMT 7779-18, p. 28 - booking.

45 Regulation (EU) 2019/1150 of the European Parliament and of the Council of 20 June 2019 on promoting fairness and transparency for business users of online intermediation services, OJ L 186/57, 11 June 2019.

46 Article 1(1) P2B regulation 2019/1150.
} 
against the use of parity clauses can result from other acts of the Union or laws of the Member States. Therefore, the P2B regulation may be limited in scope but it also leaves room for special legislation and for the application of competition law at the European or the Member State level.

In the field of European competition law, the current vertical block exemption regulation 330/2010 will expire on 31 May 2022 and the review process has already started. It will be of high relevance and interest whether and how the future regulation will address parity clauses.

Acknowledgements Open access funding provided by Max Planck Society.

Open Access This article is distributed under the terms of the Creative Commons Attribution 4.0 International License (http://creativecommons.org/licenses/by/4.0/), which permits unrestricted use, distribution, and reproduction in any medium, provided you give appropriate credit to the original author(s) and the source, provide a link to the Creative Commons license, and indicate if changes were made.

Publisher's Note Springer Nature remains neutral with regard to jurisdictional claims in published maps and institutional affiliations. 